\title{
UTOPIANISM AND JUST WAR: THE INVASION OF IRAQ IN 2003
}

\author{
Nicholas Campion \\ (University of Wales Trinity Saint David, United Kingdom)
}

\begin{abstract}
:
This article examines one of the major foreign policy disasters of recent times: the American invasion of Iraq in 2003. It explores American policy in terms of the utopian attempt to create a perfect society in Iraq based on the American model. It will locate origins for American policy in Thomas More's text and argue that, 500 years after the original publication, utopianism plays a vital role in global politics. American neoconservatism originates in two waves of reaction against the authoritarian utopianism of the revolutionary left, the first one in the 1930s and the second one that founded neoconservatism proper - in the 1960s. Turning to standard American imagery, the neoconservatives concluded that moral renewal was the only way to return to the utopian vision of America's founding fathers. It was thought that moral renewal within the USA could be encouraged by a strong foreign policy. The paper concludes is that utopias cannot be established through external force.
\end{abstract}

KEYWORDS: Iraq War, Neoconservatism, Utopia, American Foreign Policy, Neoliberalism

\section{UTOPISMO Y GUERRA JUSTA: LA INVASIÓN DE IRAK EN 2003}

\section{RESUMEN}

Este artículo examina uno de los principales desastres de política exterior de los últimos tiempos: la invasión estadounidense de Irak en 2003. Explora la política estadounidense en términos del intento utópico de crear una sociedad perfecta en Iraq, basada en el modelo estadounidense. Localiza los orígenes de la política americana en el texto de Tomás Moro y argumenta que, 500 años después de la publicación original, el utopismo juega un papel vital en la política global. El neoconservadurismo estadounidense se origina en dos oleadas de reacción contra el utopismo autoritario de la izquierda revolucionaria: el primero en la década de 1930 y el segundo -que fundó el neoconservadurismo propiamente dicho- en los años sesenta. Pasando a la imaginación colectiva norteamericana, concluyeron que la renovación moral era la 
única forma de regresar a la visión utópica de los padres fundadores de los Estados Unidos. Se pensó que la renovación moral dentro de los EE. UU. podría ser alentada por una política exterior fuerte. La conclusión es que las utopías no se pueden establecer a través de la fuerza externa.

PALABRAS CLAVE: Guerra de Irak, Neoconservadurismo, Utopía, Política exterior Americana, Neoliberalismo

\section{INTRODUCTION}

Herbert Marcuse famously wrote that «Utopia... refers to projects for change that are considered impossible» ${ }^{1}$. Yet the history of utopianism is packed with attempts to create precisely what Marcuse considered impossible. One such attempt was the American invasion of Iraq in 2003 which can be interpreted as a utopian project intended to create a perfect society in Iraq, rationalised by claims of just war as originally formulated by Thomas More $^{2}$. As More claimed, although the Utopians «detest war as a very brutal thing», they believe it can serve ethical purposes ${ }^{3}$.

The Utopian theory of just war holds that, even though war is inherently undesirable, it is permitted in cases of aggression by another power, oppression by a country of its own citizens or interference with the business interests of another, but only if diplomatic solutions are first tried and then fail. In line with More's account of utopian theory, American policy was presented as a virtuous enterprise designed to save Iraqis from the tyranny of Saddam Hussein and protect the West from Saddam's supposed weapons of mass destruction. Added to the rationalisation of the invasion as a just war, Washington's policy was influenced by a millennial belief that the global triumph of American culture was inevitable. In the eyes of American protagonists for the war, the successful creation of an American-style utopia in Iraq as a prelude to the global utopia was therefore preordained. The Americans' millennial utopian agenda was itself based in a combination of two prevalent ideologies, neoliberalism and neoconservativism. The whole account of the invasion and its aftermath then becomes an analysis of the problems (or impossibility, as Marcuse would say) of imposing utopia by force. 63.

${ }^{1}$ Herbert Marcuse, Five Lectures: Psychoanalysis, Politics and Utopia (Harmondsworth: Penguin, 1970),

${ }^{2}$ Nicholas Campion, The New Age in the Modern West: Counter-Culture, Utopia and Prophecy from the late Eighteenth Century to the Present Day (London: Bloomsbury 2015), 149-60.

${ }^{3}$ Thomas More, Utopia (London and New York: Verso, 2016), 228. 


\section{THE INVASION OF IRAQ}

At the time of writing we are now entering the fourteenth year of the civil war in Iraq. It is reasonable to suggest that the invasion was one of the biggest foreign policy disasters of modern times, equivalent to American involvement in Vietnam in the 1960s or the Soviet war in Afghanistan in the 1980s. The question is why the aftermath of the invasion of Iraq was so chaotic. One obvious reason could be simple incompetence. As Christopher Meyer, former UK ambassador to Washington wrote, «The failure to plan meticulously for Saddam's aftermath led to almost a decade of violent chaos and the ultimate humiliation of British forces» ${ }^{4}$. The initial failure to plan on a large scale resulted in a secondary failure to anticipate a range of possible consequences of the invasion. This is now well understood. For example, Michael Codner, formerly Director of the Military Sciences Department at the Royal United Services Institute, concluded that «British planning did not take into account the range of likely outcomes following invasion and regime change» ${ }^{5}$. However, when we examine the reasons for failure, incompetence can be interpreted as the result of a wider ideological perspective.

\section{THE REASONS FOR THE INVASION}

A simple reason for the invasion, popular amongst its critics, was the American desire to control Iraqi oil ${ }^{6}$. However, it was the need to replace Saddam Hussein and remove the supposed weapons of mass destruction were presented as the key reasons for the invasion: both arguments conformed to More's notion of a just war (to oppose tyranny and prevent aggression) and were set out by Colin Powell in the presentation at which he sought support from United Nations ${ }^{7}$. Yet, the desire to control Iraqi oil was openly admitted by leading American policy makers. Christopher Meyer's own testimony provides anecdotal evidence. Recalling a meeting with Paul Wolfowitz, Deputy Secretary of Defense, Meyer wrote,

I remember a meeting with an old friend, Paul Wolfowitz, a leading neo-con thinker on foreign affairs. Paul waxed fervently to me about the need to

\footnotetext{
${ }^{4}$ Christopher Meyer, "Iraq War: Sir Christopher Meyer: 'I'm with you whatever', Tony Blair told George Bush", The Daily Telegraph, 9 March, 2013,

http://www.telegraph.co.uk/news/worldnews/middleeast/iraq/9919816/Iraq-War-SirChristopher-Meyer-Im-with-you-whatever-Tony-Blair-told-George-Bush.html [accessed 14 March, 2017].

${ }^{5}$ Michael Codner, 'The Two Towers, 2001-13', in Wars in Peace: British Military Operations since 1991, ed. Adrian L. Johnson (London: Royal United Services Institute, 2014), 61-2.

6 Nafeez Ahmed, 'Iraq invasion was about oil', The Guardian, 20 March, 2014, https://www.theguardian.com/environment/earth-insight/2014/mar/20/iraq-war-oil-resourcesenergy-peak-scarcity-economy [accessed 11 March, 2017].

7 "Full text of Colin Powell's speech: US secretary of state's address to the United Nations security council,", The Guardian, 5 February, 2003, accessed 14 March, 2017, https://www.theguardian.com/world/2003/feb/05/iraq.usa [accessed 14 March 2017].
} 
extend democracy to the Middle East, create in Iraq an alternative to Saudi Arabia as an oil-producing ally of the US, and occupy forthwith the southern Iraqi oil fields, from where to undermine Saddam ${ }^{8}$.

Back in 1992 the New York Times had published leaked documents detailing American priorities in the Middle East, documenting the need to provide long-term military guarantees following the first gulf war?.

Oil security and profit therefore generated geopolitical concerns which, in turn, required a huge military presence in the area, and the creation of what John Kampfner called «a ring of American bases», which would enable «the US writ... to run everywhere $\rangle^{10}$. However, if we wish to understand why the invasion was such a failure, we need to contextualise the wider psychology of the American administration in 2003, and consider whether the USA's rationale for the invasion in terms of just war, was genuine, or just a front for a war of profit and aggression? The key occurs in Meyer's memory of Wolfowitz's desire to expand democracy to the Middle East, testimony to the sincerity of key American foreign policy makers: Wolfowitz's enthusiasm for democracy was not for public consumption but the result of deeply held beliefs. America could quite easily continue to buy oil from dictatorships, such as its close ally, Saudi Arabia, as it had for many years. It could also have worked to find a suitable modus operandi with Saddam Hussein, restoring the pragmatic alliance against Iran of the early1980s ${ }^{11}$. There was no pressing commercial need to avoid dealing with dictatorships including with Saddam.

\section{NEOCONSERVATISM AND NEOLIBERALISM}

The twin ideologies which dominated the policy of the Bush White House in the early 2000s were neoliberalism and neoconservatism. Fundamentally, neoliberalism requires the freedom to trade as far as possible without regulation, the state's role being limited to such essential roles as guaranteeing the value of money. Neoliberalism, the theory runs, is the most effective way to enhance human well-being ${ }^{12}$. In utopian terms, unregulated free trade is therefore the best guarantor of the future paradise. When Adam Smith wrote the original manifesto of what came to be neoliberal economics, he made it clear that free trade is not just one policy option, but part of the natural order of the world.

\footnotetext{
${ }^{8}$ Meyer, 'Iraq War'.

9 "Department of Defense release of the February 18, 1992 draft Defense Planning Guidance", New York Times, 8 March, 1992,

http://nsarchive.gwu.edu/nukevault/ebb245/doc03 extract nytedit.pdf [accessed 11 March 2017].

${ }_{10}$ John Kampfner, Blair's Wars (London: The Free Press, 2004), 25.

${ }_{11}$ Seymour M. Hersh, "U.S. Secretly Gave Aid to Iraq Early in Its War Against Iran," New York Times, 26 January, 1992, http://www.nytimes.com/1992/01/26/world/us-secretly-gave-aid-to-iraqearly-in-its-war-against-iran.html?pagewanted=all [accessed 11 March, 2017].

12 David Harvey, A Brief History of Neoliberalism (Oxford: Oxford University Press, 2005), 3.
} 
The uniform, constant, and uninterrupted effort of every man to better his condition, the principle from which public and national, as well as private opulence is originally derived, is frequently powerful enough to maintain the natural progress of things towards improvement, in spite both of the extravagance of government and the greatest errors of administration ${ }^{13}$.

By the 1980s neoliberalism had become a state-sanctioned utopian policy, first in the UK and USA, then spreading to first to other western countries and becoming a global movement. As Steven Lukes wrote, the 1980s saw the rise of

a new proactive and utopian "neo-liberal" right whose increasingly hegemonic ideology gripped the world in the latter part of the century with the ascendancy of Ronald Reagan and Margaret Thatcher ${ }^{14}$.

Neoliberalism adopted certain standard right wing principles, such as patriotism and a devotion to law and order, but was distinguished from mainstream conservatism in the late $20^{\text {th }}$ century by its transformation into a radical movement, challenging economic regulation and turning free markets rather than the state into a mechanism for social improvement ${ }^{15}$.In absolute terms neoliberalism and neoconservatism are fundamentally incompatible. However, they formed an alliance in the White House under George W. Bush, as well as in the policy imperatives of Margaret Thatcher, Ronald Reagan and Tony Blair, in order to reinforce the utopian drift of politics in the 1990s.

Neoconservatism has fundamentally different priorities to neoliberalism. As a utopian ideology, it requires the revival of the lost certainties of civil and social virtue, together with the regulation of public behaviour as a means of restoring the perfect society. It is essentially backwards looking, imagining a return to a lost golden age, unlike the future-oriented concerns of neoliberalism. American neoconservatism originated in two waves of reaction against the authoritarian utopianism of the revolutionary left ${ }^{16}$. The first wave took place in the 1930s, when a small number of intellectual Marxists became disillusioned with Stalinism. The second wave, and the founding of neoconservatism proper, took place in the 1960s when a group of liberal and left-wing intellectuals were horrified by the violent behaviour of many student protestors. Turning to standard American imagery, such as the Shining City on the Hill, or the New Jerusalem, such disillusioned Marxists concluded that moral renewal was the only way to return to the utopian vision of America's founding fathers.

\footnotetext{
13 Adam Smith, The Wealth of Nations (no place: Shine Classics, 2014), 187.

14 Steven Lukes, "The grand dichotomy of the twentieth century," in The Cambridge History of Twentieth Century Political Thought, ed. Terence Ball and Richard Bellamy (Cambridge: Cambridge University Press, 2003), 623. https://doi.org/10.1017/CHOL9780521563543.030

15 Patricia Ventura, Neoliberal Culture: Living with American Liberalism (Farnham: Ashgate 2012).

${ }^{16}$ Campion, The New Age in the Modern West, 150-1.
} 
Discussion of utopianism was itself a feature of the rejection of revolutionary Marxism. The classic text of the 1930s proto-neoconservatives was Eugene Lyons' memoire Assignment in Utopia, utopia here being used ironically to refer to the Soviet Union $^{17}$. And in one of the foundational texts of post-war neoconservatism, the sociologist Daniel Bell announced that the end of the ideological struggle between Left and Right, which he thought had arrived with the discrediting of the Left, need not include the loss of utopian hopes:

The end of ideology is not - should not be the end of utopia as well. If anything, one can begin anew the discussion of utopia only by being aware of the trap of ideology...There is now, more than ever, some need for utopia, in the sense that men need - as they have always needed - some vision of the potential, some manner of using passion with intelligence. Yet the ladder to the City of Heaven can no longer be a "faith ladder", but an empirical one ${ }^{18}$.

Neoconservatism's prime focus was not on economics but on the perceived collapse of social values, and Bell believed that, in order to be successful, utopian policy should in future be based less on Biblical imagery, than on detailed sociological data. However, the fact of moral decay was taken as a given. As Gertrude Himmelfarb wrote, «civil society has been infected by the same virus that has contaminated the entire culture: irresponsibility, incivility, a lack of self-discipline and self-control» ${ }^{19}$. Neoconservatism's core concern was the need to reverse moral decay at home, and foreign policy was secondary, if still important. For example, Bell thought that a symptom of moral collapse amongst anti-war protesters in the 1960s was their acceptance of communism, as evident in the popular iconography of Mao Tse-tung and Ho Chi-Minh. This in turn was thought to have resulted in a weakening of anticommunism as the key plank of American foreign policy, as evident in détente. Neoconservative theory held that such moral renewal could be encouraged by a strong foreign policy, as described by Peter Steinfels:

A precarious international order requires a stable, unified society at home; renewed emphasis on the Communist threat and on the Third World's rejection of liberal values is needed to generate the requisite national allegiance and discipline ${ }^{20}$.

Neoconservative foreign policy, then, was initially essentially negative, requiring an enemy abroad in order to encourage moral renewal at home.

${ }^{17}$ Eugene Lyons, Assignment in Utopia (London: George C. Harrap, 1938).

${ }^{18}$ Daniel Bell, The End of Ideology: On the Exhaustion of Political Ideas in the Fifties (New York: The Free Press, 1962), 405.

${ }^{19}$ Gertrude Himmelfarb. 'This Will Hurt'. In This Will Hurt: The Restoration of Virtue and Civic Order, The Social Affairs Unit, Digby Anderson (ed.), 1995, x. 71.

${ }^{20}$ Peter Steinfel. The Neoconservatives: The Origins of a Movement (New York: Simon and Schuster, 2014), 


\section{FRANCIS FUKUYAMA AND NEOCONSERVATIVE FOREIGN POLICY}

Neoconservative foreign policy took on a new lease of life in 1989 as a result of the disintegration of the communist regimes of Eastern Europe. Enthused by that year's wave of popular revolutions, the foreign policy analyst Francis Fukuyama announced that the end of ideological struggle proclaimed by Daniel Bell in 1962 had finally arrived with the triumph of American-style liberal democracy and free-market economics ${ }^{21}$. Fukuyama shared the neoconservatives' pessimism over the condition of the west, writing that «We in the West have become thoroughly pessimistic with regard to the possibility of overall progress in democratic institutions» ${ }^{22}$. But then, he added, "good news has come», the cause for optimism being the progressive collapse of all the world's dictatorships under the weight of their own inadequacies, spreading the example of eastern Europe to other regions, such as the Middle East ${ }^{23}$. This is what Fukuyama meant by the end of history. The "last man" of his title was actually to be the product not just of the triumph of American culture but of the scientific manipulation of humanity, achieving what decades of social engineering had failed to accomplish: «we shall then» he wrote, «finally have definitely finished human history, because we shall have abolished human beings as such. And then a new, post-human history will begin $\rangle^{24}$. Fukuyama did not appeal to utopia as his model, but his theories were deeply utopian in their anticipation of future perfection.

Fukuyama's most significant philosophical influence was Georg Frederick Hegel, arguably the most important of the Enlightenment Platonists. In Hegel's millennial vision history is driven by the gradual unfolding of the Platonic world soul originally imagined in Timaeus ${ }^{25}$. He believed that in the final, inevitable, perfected state of existence, all cause of conflict would be resolved, hence Fukuyama's belief in the end of history. Hegelianism, the ideology derived from Hegel, often adopts a deterministic view of a goal-oriented history which is bound to arrive at a final destination. Hegel himself was somewhat more equivocal, for while there is an end and a purpose, its precise form is unknown ${ }^{26}$. The final state may be Germany, or it may be the United States, but this is for individual Hegelians to decide and doesn't matter as long as it is the advanced, industrial regions of the white, Protestant, AngloSaxon world. Either way, the Hegelian utopia lies in the end of history.

${ }^{21}$ Frances Fukuyama, 'The End of History?', The National Interest, no 16, Summer 1989, 3-18; Frances Fukuyama, The End of History and the Last Man, London: Penguin, 1991.

${ }^{22}$ Fukuyama, The End of History, xiii.

${ }^{23}$ Fukuyama, The End of History, xiii.

${ }^{24}$ Fukuyama, 'The end of history?', 4.

25 Plato, Timaeus, trans. R.G. Bury (Cambridge Mass., London: Harvard University Press 1931), 41D; G.W.F. Hegel, The Philosophy of History, trans. J. Sibree (New York: Dover Publications, 1956), 442.

${ }^{26}$ Eric Dale, Hegel, the End of History and the Future (Cambridge: Cambridge University Press, 2014), 3. https://doi.org/10.1017/CBO9781107477711 
The driver of Fukuyama's millenarian narrative was psychological and humanist - the supposed need of the thymos, part of the Platonic soul, for recognition and self-esteem. ${ }^{27}$ It was this need, Fukuyama argued, which had provoked the oppressed citizens of the communist world to rebel. Fukuyama's claim that the end of communism and the triumph of the USA were both written into both the psychic fabric of humanity and the inexorable direction of history was enthusiastically adopted by the neoconservatives, for whom it demonstrated the inevitable triumph of their cause. The result was the foundation in 1997 of the think-tank, "The Project for the New American Century". Fukuyama himself was one of the original 25 signaturees, and the Chairman was the leading neoconservative, William Kristol. According to its own vision statement, the Project was,

dedicated to a few fundamental propositions: that American leadership is good both for America and for the world; and that such leadership requires military strength, diplomatic energy and commitment to moral principle (and was intended to) strive to rally support for a vigorous and principled policy of American international involvement...28

The neoconservatives' initial negative policy, which required only the presence of an enemy, was transformed into a positive policy in which the enemy should be attacked and overthrown. From the outset the Project campaigned actively for an invasion of Iraq. For example, a memorandum of 7 January 1999, twenty months before the 9/11 attacks on the New York Twin Towers, argued that «Now that the dust has settled from the 70-hour aerial attack on Iraq, it has become clear that the only solution for the threat Iraq poses is to remove Saddam» ${ }^{29}$. John Kampfner recalled that

Prior to the invasion, the neoconservatives' optimism had known no bounds: "After Baghdad, Beijing" ran one boast. They saw especially in the Middle East a web of corrupt dictators, whose people would, if given the chance, embrace a Jeffersonian view of democracy. Iraq was top of the lis $t^{30}$.

The neoconservatives' Jeffersonian optimism was justified by Fukuyama's prophecy of the inevitability of the triumph of American values; any invasion of Iraq was therefore bound to be successful precisely because of this inevitability. It was this belief that accounts for the failure to plan, and even what appears to be incompetence can be interpreted as a result of the belief that no planning was necessary, for success

${ }^{27}$ Fukuyama, The End of History, 163; also see 223-34, 300-12.

28 The Project for the New American Century, archived copy from 9 June, 2013, https://web.archive.org/web/20130609154959/http://www.newamericancentury.org/ [accessed 24 July, 2014].

${ }^{29}$ Mark Lagon, "Memorandum to Opinion Leaders", The Project for the New American Century, January 7 ,

https://web.archive.org/web/20130609165624/http://www.newamericancentury.org/iraqjan0799.ht m [accessed 24 July, 2014].

${ }^{30}$ Kampfner, Blair's Wars, 25. 
was assured. It was Fukuyama himself who later denounced this position on the grounds that the historical process had to be allowed to take its own course ${ }^{31}$. He argued that to promote regime change and actively seek to depose Saddam was therefore contrary to the law of history. However, after 9/11 the US administration revised its foreign policy. The new priorities were outlined by George W. Bush in November 2003, after the invasion of Iraq, in the first of a series of speeches. He announced a new "forward strategy" intended to promote democracy in the Middle East as the only sure guarantor of peace ${ }^{32}$. The policy consisted of three pillars. One was military dominance, in line with the 1992 defence review. The other two were preemption and regime change, both of which represented radical breaks with previous American policy in the Middle East, and assumed that the pace of history could be forced.

Can the pace of history be forced? Fukuyama thought not, but the Project for the New American Century thought it could. The question is an established one in millennial thought and had been the essence of Lenin's argument in 1902, when he attacked social democrats for being diverted into reformism and instead argued for the creation of a revolutionary vanguard in order to promote revolution, rather than wait for it to take place in its own time ${ }^{33}$. In 1917 Lenin was distinguished from many of his fellows by his belief that Russia, which was hardly ready for a transition to the dictatorship of the proletariat, might still be pushed into revolution. The guiding ideology behind neoconservative foreign policy may then be described as what the political scientist Ken Jowitt called "Marx-Fukuyama"34. Jowitt argued simply, if that if the notion of forced historical change is then Leninist, then the notion of forced regime change as formulated by the neoconservatives becomes Leninist.

\section{IMPLEMENTING UNIVERSAL HISTORY IN IRAQ}

The argument that failure in Iraq was the consequence of blind optimism and a complete lack of attention to local conditions is found in Fukuyama's own repudiation of the neoconservatives ${ }^{35}$. There were two main strands in the American reform programme in Iraq, one economic and the other political, both of which ignored local conditions. They were implemented together by Paul Bremer, head of the Coalition Provisional Authority, who disbanded the organs of Saddam's rule, the Baath Party and the army, and instituted a policy of neo-liberal privatisation. What

${ }^{31}$ Francis Fukuyama, After the Neocons: America at the Crossroads (London: Profile Books, 2007).

32 'Bush demands Mid-East democracy', BBC News 6 November 2003, http://news.bbc.co.uk/1/hi/world/middle east/3248119.stm [accessed 25 April 2015].

33 Vladimir Ilyich Lenin, "What is to be Done?", in Essential Works of Lenin (no place: bn publishing 2015), 137.

${ }^{34}$ Kenneth Jowitt, New World Disorder: The Leninist Extinction (Berkeley: University of California Press, 1992), 88; Kenneth Jowitt, 'Rage, Hubris and Regime Change: The Urge to Speed History Along'. Policy Review 118 (April-May 2003): 34-8. http://www.hoover.org/research/rage-hubris-and-regime-change [accessed 1 October 2014].

${ }^{35}$ Fukuyama, After the Neocons, 95. 
Bremer called «the switch from value-destroying public enterprises to value-creating private ones», would then, he hoped, provide a foundation for a free, democratic system. ${ }^{36}$ As Christopher Meyer later wrote, «we were, in effect, telling the Iraqi people to please start the business of nation-building all over again... $\rangle^{37}$. This was all done with absolutely no reference to existing conditions in the Iraqi economy. Quite the reverse, the belief was not only would the whole world become American, but that it wanted to be American. Thomas Friedman, a huge fan of Fukuyama had written that «Culturally speaking globalization has tended to involve the spread of Americanization - from Big Macs to iMacs to Micky Mouse ${ }^{38}$. Neither was there any attention to local political conditions. One example has been described by Rory Stewart who served as part of the British administration in southern Iraq. Stewart recalled how

An American expert came from Baghdad to do 'capacity building' with the local council. On a white board he drew an oblong in its side, to represent the council, and then beneath it four vertical oblongs, to represent its subcommittees. 'He is drawing a dog', said a sheikh. 'Are we going back to primary school?' asked another. We are an ancient civilisation,' said one cleric, 'and they treat us like Congo cannibals. ${ }^{39}$

Such behaviour may sound like simple stupidity - a complete failure to comprehend the need to engage with Iraqi culture. But then it becomes clear that for the visiting expert, democracy is a universal condition, absolutely the same in all circumstances regardless of history or culture: «Welcome to your new democracy, said the democracy expert. I have met you before. I have met you in Cambodia I have met you in Russia. I have met you in Nigeria» ${ }^{40}$.

Two members of the council promptly walked out. The assumption, in Timothy Mitchells' words, was that «For an expert on democracy, democratic politics is the same everywhere... Democracy is based on a model, an original idea, that can be copied from one place to the next» ${ }^{41}$. It was, in effect, a Platonic archetype, eternal, universal and applicable equally in all places at all times. Reality was equally ignored by British policy makers. Here is Christopher Meyer again, this time on Tony Blair.

With his Manichean, black-and-white view of the world, Mr Blair was in his way more neo-con than the neo-cons, more evangelical than the American Christian Right. From this flowed Britain's contribution to the mistakes made

36 L. Paul Bremer III, "Operation Iraqi Prosperity", Wall Street Journal, 20 June, 2003, http://online.wsj.com/news/articles/SB105606663932885100 [accessed 14 October, 2014]; see also Fukuyama, After the Neocons, 8 and Harvey, Neoliberalism, 4-5.

${ }^{37}$ Christopher Meyer, "Our national interest demands the mother of all U-turns." The Daily Telegraph, 23 August, 2014, http://www.telegraph.co.uk/news/worldnews/middleeast/iraq/11051734/Ournational-interest-demands-the-mother-of-all-U-turns.html [accessed $15 \mathrm{March}, 2017]$.

38 Thomas Friedman, The Lexus and the Olive Tree (New York: Farrar, Strauss and Giroux, 1999), 9.

${ }^{39}$ Rory Stewart, Occupational Hazards: My Time Governing in Iraq (London: Picador, 2006), p. 280; also see Timothy Mitchell, Carbon Democracy: Political Power in the Age of Oil (London: Verso, 2011), 2.

40 Stewart, Occupational Hazards, 281.

${ }^{41}$ Mitchell, Carbon Democracy, 5. 
before and after the Iraq invasion, despite repeated warnings from the Foreign Office and the Washington embassy ${ }^{42}$.

For the neoconservatives, to lead the world to freedom was a bold dream but in the idea that history could be reset, it was reminiscent of the Jacobins' revolutionary calendar or the Khmer Rouge's Year Zero, in the idea that history could be reset. As Jowitt wrote, the belief that American-style democracy could be established in Iraq and the Middle East possessed 'all the unreality of Don Quixote'. ${ }^{43}$ It only existed in the realms of utopian impossibility.

\section{CONCLUSION}

The invasion of Iraq was launched as a just war within the definition outlined by Thomas More -to overthrow tyranny and resist aggression- and was intended to promote utopian ideals. The assumption that America has the finest system political and economic system in the world, together with the millennial belief that the entire world is bound by the law of history to become American, underpinned what was essentially an attempt to build utopia in Iraq. The reason for the lack of planning in Iraq was that for neoconservatives no planning was necessary; the metaphysics of history dictated that once Saddam Hussein had been overthrown, Iraq must of necessity become a neoliberal free market and an American style democracy as envisaged by the neoconservatives. From a domestic point of view, Iraq also then became a useful enemy. The invasion's goals failed because the utopian ideal was confused with the idea of a directional history in which the end-goal was inevitable and the belief that the pace of this directional history could be forced. Daniel Bell's assertion that utopia should be built on the basis of empirical data rather than faith was ignored and the result has been not utopia but dystopia. There is no clearer evidence that utopias cannot be established through external force.

\section{BIBLIOGRAPHY}

BBC News. "Bush demands Mid-East democracy," 6 November, 2003, http://news.bbc.co.uk/1/hi/world/middle east/3248119.stm [accessed 25 April 2015].

The Project for the New American Century, archived copy from 9 June, 2013, https://web.archive.org/web/20130609154959/http://www.newamericance ntury.org/ [accessed 24 July 2014].

\footnotetext{
${ }^{42}$ Meyer, 'Iraq War'.

${ }^{43}$ Jowitt, 'Rage, Hubris and Regime Change'
} 
New York Times. "Department of Defense release of the February 18, $1992 \mathrm{draft}$ Defense Planning Guidance," 8 March, 1992 http://nsarchive.gwu.edu/nukevault/ebb245/doc03 extract nytedit.pdf.[acc essed 11 March 2017].

Bell, Daniel, The End of Ideology: On the Exhaustion of Political Ideas in the Fifties (New York: The Free Press, 1962).

Campion, Nicholas, The New Age in the Modern West: Counter-Culture, Utopia and Prophecy from the late Eighteenth Century to the Present Day (London: Bloomsbury 2015).

Codner, Michael. "The Two Towers, 2001-13", in Wars in Peace: British Military Operations since 1991, ed. Adrian L. Johnson (London: Royal United Services Institute, 2014).

Dale, Eric, Hegel, the End of History and the Future (Cambridge: Cambridge University Press, 2014). https://doi.org/10.1017/CBO9781107477711

Friedman, Thomas, The Lexus and the Olive Tree (New York: Farrar, Strauss and Giroux, 1999).

Fukuyama, Frances, “The End of History?”, The National Interest 16 (1989): 3-18.

Fukuyama, Francis, The End of History and the Last Man (London: Penguin, 1991).

Fukuyama, Francis, After the Neocons: America at the Crossroads (London: Profile Books, 2007).

Harvey, David, A Brief History of Neoliberalism (Oxford: Oxford University Press, 2005).

Hegel, G. W. F., The Philosophy of History, translated by J. Sibree (New York: Dover Publications, 1956).

Hersh, Seymour M., "U.S. Secretly Gave Aid to Iraq Early in Its War Against Iran", New York Times, 26 January 1992, http://www.nytimes.com/1992/01/26/world/us-secretly-gave-aid-to-iraqearly-in-its-war-against-iran.html?pagewanted=all [accessed 11 March 2017].

Himmelfarb, Gertrude. "This Will Hurt". In This Will Hurt: The Restoration of Virtue and Civic Order, The Social Affairs Unit, ed. Digby Anderson, ix-xi (London: The Social Affairs Units, 1995).

Jowitt, Kenneth, New World Disorder: The Leninist Extinction (Berkeley: University of California Press, 1992). 
Jowitt, Kenneth, "Rage, Hubris and Regime Change: The Urge to Speed History Along", Policy Review 118 (2003): 34-8, http://www.hoover.org/research/ragehubris-and-regime-change [accessed 1 October 2014].

Kampfner, John, Blair's Wars (London: The Free Press, 2004).

Lagon, Magon, "Memorandum to Opinion Leaders," The Project for the New American Century, January $\quad 7 \quad 1999$, https://web.archive.org/web/20130609165624/http://www.newamericance ntury.org/iraqjan0799.htm [accessed 24 July 2014].

Lenin, Vladimir Ilyich, "What is to be Done?", in Essential Works of Lenin (no place: bn publishing 2015), 54-175.

Lukes, Steven, "The grand dichotomy of the twentieth century", in The Cambridge History of Twentieth Century Thought, ed. Terence Ball and Richard Bellamy (Cambridge: Cambridge University Press, 2003), 602-626. https://doi.org/10.1017/CHOL9780521563543.030

Lyons, Eugene, Assignment in Utopia (London: George C. Harrap, 1938).

Herbert Marcuse, Five Lectures: Psychoanalysis, Politics and Utopia (Harmondsworth: Penguin, 1970).

Meyer, Christopher, "Iraq War: Sir Christopher Meyer: 'I'm with you whatever', Tony Blair told George Bush," The Daily Telegraph, 9 March 2013,

http://www.telegraph.co.uk/news/worldnews/middleeast/iraq/9919816/Iraq-WarSir-Christopher-Meyer-Im-with-you-whatever-Tony-Blair-told-GeorgeBush.html [accessed 15 March 2017].

Meyer, Christopher, "Our national interest demands the mother of all U-turns," The Daily Telegraph, 23 August 2014, http://www.telegraph.co.uk/news/worldnews/middleeast/iraq/11051734/ Our-national-interest-demands-the-mother-of-all-U-turns.html [accessed 15 March 2017].

Mitchell, Timothy, Carbon Democracy: Political Power in the Age of Oil (London: Verso, 2011).

More, Thomas, Utopia (London and New York: Verso, 2016).

Plato, Timaeus, trans. R.G. Bury (Cambridge Mass. - London: Harvard University Press, 1931).

Smith, Adam, The Wealth of Nations (no place: Shine Classics, 2014). 
Steinfels, Peter, The Neoconservatives: The Origins of a Movement (New York: Simon and Schuster, 2014).

Stewart, Rory, Occupational Hazards: My Time Governing in Iraq (London: Picador, 2006).

Recibido: 3 de mayo de 2017 Aprobado: 9 de octubre de 2017 